\title{
Modification of warumbia cultivar brown rice flour (Oryza sativa L.) using SBM.3D lactic acid bacteria
}

\author{
Sri Wahyuni ${ }^{{ }^{*}}$, Andi Khaeruni $^{2}$, Asnani ${ }^{3}$, Sarinah ${ }^{1}$, RH Fitri Faradilla ${ }^{1}$, Wa Ode Syamnawar \\ Rizka $^{1}$, and Erlisa Salim ${ }^{1}$ \\ ${ }^{1}$ Department of Food Science and Technology, Faculty of Agriculture, Halu Oleo University, \\ Kendari, Indonesia \\ ${ }^{2}$ Department of Plant Protection, Faculty of Agriculture, Halu Oleo University, Kendari, Indonesia \\ ${ }^{3}$ Departmen of Aquatic Product Technology, Faculty of Fisheries and Marine Science, Halu Oleo \\ University, Kendari, Indonesia
}

\begin{abstract}
The research purpose was to determine the optimum fermentation time and SBM.3D LAB concentration on the physicochemical of modified Warumbia brown rice flour. This research uses a Completely Randomized Design with a factorial pattern consisting of two factors that are the length of fermentation and the concentration of $\mathrm{LAB}$. The results showed that the interaction of the fermentation time treatment and SBM.3D LAB concentration had a significant effect on the characteristics of physicochemical properties of the viscosity and $\mathrm{pH}$ variables. However, it had no significant effect on the swelling power and water solubility index of the modified Warumbia brown rice flour. The best fermentation treatment was obtained at 48 hours of fermentation time with OD 0,75 of SBM.3D LAB concentration. The treatment had viscosity value of $25.00 \mathrm{cP}$, swelling power of $9.15 \mathrm{~g} / \mathrm{g}$, water solubility index of $31.73 \%$ and $\mathrm{pH}$ value of 6.10 . The proximate content Warumbia brown rice flour are water content $8.37 \% \mathrm{wb}$, ash content $0.66 \% \mathrm{db}$, protein content $5.65 \% \mathrm{db}$ and glucose content $16.57 \% \mathrm{db}$. The results showed that the interaction between fermentation time and SBM.3D LAB concentration had a significant effect on increasing physicochemical properties and proximate content of the modified Warumbia brown rice flour.
\end{abstract}

\section{Introduction}

Rice is one of the staple foods for several densely populated countries such as Indonesia. According to the Statistics Indonesia [1], rice production in Indonesia reached 32.42 million tons. Meanwhile, in Southeast Sulawesi Province, the total rice production in 2018 reached 499.01 thousand tons [2]. According to Savira [3], North Buton is now known as an organic regency which has 22 types of local rice, including Warumbia cultivar brown

\footnotetext{
*Coresponding author: $\underline{\text { rriwahyuni aan@yahoo.com }}$
} 
rice which can be found throughout its territory with a productivity of 2.5 tons per ha. One form of rice diversification is processing it into semi-finished products in the form of flour for further industrial raw materials [4]. However, there are several weaknesses in its characteristics, such as the low ability to hold gas when the dough expands as a whole [5], and the results of some processed products have a hard and coarse texture. This weakness causes the use of rice flour as raw material for processing various food products is still limited. Therefore, it is necessary to use a starch modification method to improve the characteristics of the rice flour that will be produced.

Starch modification is considered to improve the characteristics of flour. Nurhayati et al. [6] reported that fermentation using Lactobacillus casei for 48 hours could produce good characteristics of rice flour on the values of water content, amylose content and amylopectin content, respectively, $8.69 \%, 27.95 \%$ and $40.89 \%$. Helmi [7] reported that the process of modifying foodstuffs with starter fermentation in the form of lactic acid bacteria (LAB) was useful for reducing the number of pathogenic bacteria, preserving food and improving the quality of the produced flour.

Carbohydrate content is quite high in rice, which is as much as $79.34 \mathrm{~g}$ per $100 \mathrm{~g}$ of material which has the potential as a source of the growth of lactic acid bacteria [8]. According to Adnan [9], the results of the isolation and screening of $10 \mathrm{LAB}$ isolates from Wakawondu red rice washing water fermentation obtained a superior isolate, namely SBM.3D which had advantages as probiotic agents and was selected based on the ability to degrade starch and casein which was quite large with the ability to grow at low $\mathrm{pH}$. According to Zikirah [15] in his research using SBM LAB which had been isolated and screened by Adnan [9] in the manufacture of yam flour, LAB that grew in the fermentation process produced amylase enzymes that could destroy starch cell walls, resulting in the release of starch granules [16]. The release of the starch granules will cause changes in the characteristics of the produced flour, that is increase in viscosity, swelling power and WSI [17].

Based on the description above, this research reports the results of the modification of Warumbia brown rice flour using lactic acid bacteria that had been isolated and screened by Adnan [9] from the washing water of Wakawondu brown rice SBM.3D isolate in the hope of improving the characteristics of the flour which has physicochemical and functional properties.

\section{Materials dan methods}

\subsection{Material}

The main ingredients used were Warumbia cultivar brown rice and Lactic Acid Bacteria (LAB) which had been isolated and screened by Adnan [9] from the washing water of Wakawondu brown rice SBM.3D isolate. The materials used for the manufacture of LAB growth media were MRS-Agar (Merck), alcohol (Merck) and chemicals for proximate analysis from Merck.

\subsection{Fermentation of Warumbia Cultivar Brown Rice Using SBM.3D LAB Isolate}

Before fermenting the Warumbia cultivar brown rice with the LAB isolate, the SBM.3D LAB isolate was first rejuvenated. After that, the growth of SBM.3D was measured in the $\log$ phase, before measuring the value of optical density (OD) $(0.50 ; 0.75$ and 1.00$)$. The measurement of OD value using UV-Vis spectrophotometry was based on the turbidity of 
the solution with a wavelength of $600 \mathrm{~nm}$. Next, Warumbia cultivar brown rice to be fermented with LAB. Time fermentation treatment was carried out at 24, 48, and 72 hours at temperature of $37^{\circ} \mathrm{C}$ (Solid state fermentation method). The fermentation process was carried out under sterile conditions to prevent contamination [10].

\subsection{Making Modified Warumbia Cultivars Brown Rice Flour}

The fermented Warumbia cultivar brown rice was washed thoroughly using sterile water, then dried using an oven at $60^{\circ} \mathrm{C}$ for 24 hours. After drying, the rice was mashed using a blender and then sieved using a 100-mesh sieve to get 100 mesh rice flour.

\subsection{Characterization of Physicochemical Properties of Modified Warumbia Cultivar Brown Rice Flour}

\subsubsection{Viscosity Analysis}

Viscosity analysis was performed using Oswald viscometer (Oswald method). This test was carried out by calculating the time required for the Warumbia cultivar brown rice flour solution which had reached its maximum point to flow from the Oswald viscometer until it reached the stopping point. [11].

\subsubsection{Swelling Power and Water Solubility Index Analyses}

The starch suspension solution with a concentration of $1 \%$ was heated at $90^{\circ} \mathrm{C}$ for 30 minutes, then was centrifuged at $3000 \mathrm{rpm}$ for 15 minutes. After that, the supernatant was separated from the precipitate. Swelling power is the ratio between the weight of the precipitate left in the centrifuge tube and the dry weight of the sample, while water solubility index is the weight percentage of starch that is soluble in water [12].

\subsection{3 $\mathrm{pH}$ Value Analysis}

The $\mathrm{pH}$ value was measured using a digital $\mathrm{pH}$ meter ATN 105. After calibration, the sample was measured by making a $10 \%$ suspension of the sample in water.

\subsubsection{Gel Visual Analysis}

Visual analysis of the gel refers to the method that has been carried out by Imanningsih [13], which is dissolving $3 \mathrm{~g}$ of sample into $25 \mathrm{ml}$ of distilled water and heated for 5 minutes. The sample was placed on a glass slide to observe the visual appearance of the gel and then documented.

\subsubsection{FTIR Analysis}

Flour was analyzed using Fourier Transform Infrared Spectroscopy (FTIR). Flour was pelleted with $\mathrm{KBr}$ using manual compression equipment (Shimadzu, Tokyo, Japan).

\subsubsection{X-Ray Difraction (XRD) Analysis}

Flour was characterized using the X-ray diffraction technique (XDR JEOL JDX-3530 Xray diffractometer) to determine the crystalline phase and crystallinity. 


\subsubsection{Rapid Visco analyzer (RVA) Analysis}

The starch's gelatinization profile was revealed by the analysis using a Rapid Visco Analyzer (RVA, Newport Scientific Warriewood, Australia). The sample was treated according to the temperature and time program that had been set, namely heating until peak viscosity was obtained, holding for five minutes, and cooling [13].

\subsubsection{Chemical Composition Analysis}

The AOAC standard [14] was used to analyze water, ash, protein, and glucose content.

\section{Result and Discussion}

\subsection{Physicochemical Characterization of Modified Warumbia Cultivar Brown Rice Flour}

The best result on the physicochemical characteristics of the modified Warumbia cultivar brown rice flour was obtained at 48 hours of fermentation using SBM.3D LAB isolate. Ashari [10] the increase in fermentation time can cause the nutrients in the LAB growth media to decrease, so that the LAB hydrolysis ability decreases. Nutritional deficiencies can be influenced by the number of LAB populations that are too large in a media, causing competition to obtain nutrients.

Table 1. Effects of LAB concentration and fermentation time on the value of viscosity, swelling power, solubility, and $\mathrm{pH}$ of modified Warumbia brown rice flour

\begin{tabular}{|c|c|c|c|c|c|}
\hline \multirow{2}{*}{$\begin{array}{c}\text { LAB } \\
\text { Concentratio } \\
\mathbf{n}\end{array}$} & \multirow{2}{*}{$\begin{array}{c}\text { Fermentatio } \\
\mathbf{n} \text { Time }\end{array}$} & $\begin{array}{c}\text { Viscosity } \\
\mathbf{( c P )}\end{array}$ & $\begin{array}{c}\text { Swelling } \\
\text { Power (g/g) }\end{array}$ & $\begin{array}{c}\text { Water } \\
\text { Solubility } \\
\text { Index (\%) }\end{array}$ & pH \\
\hline 0 & 0 hours & $\begin{array}{c}13.67 \pm 0 . \\
10\end{array}$ & $5.70 \pm 1.29$ & $21.33 \pm 2.31$ & $6.40 \pm 0.00$ \\
\hline OD 0.50 (R1) & 24 hours & $\begin{array}{c}19.83 \pm 0 . \\
51\end{array}$ & $6.52 \pm 0.17$ & $26.66 \pm 1.01$ & $6.00 \pm 0.00$ \\
\hline OD 0.75 (R2) & 24 hours & $\begin{array}{c}21.22 \pm 1 . \\
10\end{array}$ & $7.52 \pm 0.28$ & $27.46 \pm 1.29$ & $6.00 \pm 0.00$ \\
\hline OD 1.00 (R3) & 24 hours & $\begin{array}{c}20.62 \pm 0 . \\
72\end{array}$ & $7.28 \pm 0.78$ & $26.93 \pm 0.61$ & $6.03 \pm 0.06$ \\
\hline OD 0.50 (R1) & 48 hours & $\begin{array}{c}21.91 \pm 0 . \\
59\end{array}$ & $7.95 \pm 0.04$ & $29.46 \pm 2.66$ & $6.00 \pm 0.00$ \\
\hline OD 0.75 (R2) & 48 hours & $\begin{array}{c}25.00 \pm 0 . \\
28\end{array}$ & $9.15 \pm 0.99$ & $31.73 \pm 3.03$ & $6.10 \pm 0.00$ \\
\hline OD 1.00 (R3) & 48 hours & $\begin{array}{c}22.18 \pm 0 . \\
16\end{array}$ & $8.08 \pm 0.03$ & $29.73 \pm 0.46$ & $6.00 \pm 0.00$ \\
\hline OD 0.50 (R1) & 72 hours & $\begin{array}{c}21.19 \pm 0 . \\
36\end{array}$ & $8.10 \pm 0.31$ & $29.86 \pm 1.40$ & $5.90 \pm 0.00$ \\
\hline OD 0.75 (R2) & 72 hours & $\begin{array}{c}22.88 \pm 0 . \\
38\end{array}$ & $8.56 \pm 0.18$ & $30.53 \pm 3.45$ & $5.93 \pm 0.06$ \\
\hline OD 1.00 (R3) & 72 hours & $\begin{array}{c}21.77 \pm 0 . \\
21\end{array}$ & $8.31 \pm 0.66$ & $30.13 \pm 1.80$ & $5.90 \pm 0.00$ \\
\hline
\end{tabular}

Based data on Table 1, it was found that the selected treatment for the modified Warumbia cultivar brown rice flour was using SBM.3D LAB isolate at a concentration of $\mathrm{OD}=0.75$ and a fermentation time of 48 hours. 


\subsubsection{Viscosity}

Viscosity can be used as an indicator of the level of ease of cooking and also shows the strength of the dough formed from gelatinization during the processing in food product applications [19]. Table 1. shows that the highest viscosity value of the modified Warumbia brown rice flour using SBM.3D LAB isolate was the fermentation for 48 hours at a concentration of OD 0.75 with a value of $25.00 \mathrm{cP}$. The viscosity value of the modified Warumbia brown rice flour increased at 24 and 48 hours of fermentation. However, there was a decrease in the viscosity value of Warumbia brown rice flour as the concentration of SBM.3D LAB increased, presumably because the longer the fermentation, the more amylase enzyme degraded the amylose chains into a shorter structure and was followed by a decrease in the viscosity value of the flour (Winarno, 1995).

The increase in the viscosity value was influenced by the fermentation process using LAB. LAB produced amylase enzymes that could cause starch degradation during the fermentation process, namely by breaking or hydrolyzing amylose and amylopectin chains at $\alpha-1,4$ glycosidic bonds into shorter polymers [20]. During the heating process of starch suspension using excess water, the water that moved freely outside the granules was absorbed into the starch granules and trapped in it, causing the viscosity to increase (Fais, 2015). The process of permeation of water into the granules caused the swelling of the starch granules to a certain extent before the starch granules broke or starch gelatinization occured. Thus, at the time of gelatinization, the starch amylose chains began to diffuse out of the starch granules and caused the structure of the starch granules to become more tenuous so that they would form a thick paste and increased the viscosity of the modified Warumbia brown rice flour.

\subsubsection{Swelling Power}

Based on the data in Table 1. the swelling power value of the Warumbia brown rice flour which had been modified using fermentation with SBM.3D LAB isolate for 48 hours at a concentration of OD 0.75 produced a swelling power value of $9.15 \mathrm{~g} / \mathrm{g}$ which had the highest increase compared to the other treatment. The increase in the swelling power value of modified flour during heating shows that the fermentation process that occurs in flour involves bacteria that produce enzymes that hydrolyze $-1,4$ glycosidic bonds in the starch chains so that the starch chains will be shorter (Diniyah et al., 2018) and cause more water absorbed during the cooking process. The absorption of water in each starch granule will make the starch granules expand and coincide with each other, thereby increasing the swelling power value of the modified flour [21].

The decrease in swelling power value in the flour with increasing concentration of SBM.3D LAB is presumed to be due to the hydrolysis of the straight chain portion of amylopectin in starch. Amylopectin integrity plays an important role in swelling power and in the granule structure (Diniyah et al., 2018). Budiyati et al. (2016) stated that if the straight chain part of amylopectin is hydrolyzed, there is a decrease in the stability of starch to absorb water which results in a decrease in the swelling power of Warumbia brown rice flour.

\subsubsection{Water Solubility Index}

The results of the research in Table 1. shows that the value of the water solubility index of the modified Warumbia brown rice flour had increased in the treatment using SBM.3D LAB isolate in the fermentation for 48 hours with a concentration of OD 0.75 with a value of $31.73 \%$. Production of amylase enzymes by LAB activity during the fermentation 
process which can degrade starch polymer chains by cutting $\alpha-1,4$ glycosidic bonds in starch into shorter polymer chains, making it more soluble in water. The presence of a smaller molecular size makes it easy to dissolve in water.

The decrease in the value of the water solubility index in the fermented brown rice flour is presumed to be due to the long fermentation time which causes more amylase enzymes to be produced so that the degradation of amylose chains increases. When the amount of amylose that has been bound to water continues to increase, it will leave a part of the amylopectin branched chain that cannot be degraded by the amylase enzyme. This will decrease the value of the solubility index in the water, due to the nature of amylopectin branched chains which are not easily soluble in water [31].

\subsection{4 $\mathrm{pH}$}

Based on the results in Table 1. the highest $\mathrm{pH}$ value of modified Warumbia brown rice flour using SBM.3D LAB isolate was the fermentation for 48 hours at a concentration of OD 0.75 with a value of 6.10 . Fermentation time tends to make the $\mathrm{pH}$ value of the acid decrease. This is because LAB can produce acidic compounds during the fermentation process[22]. The decrease in $\mathrm{pH}$ value is due to the accumulation of lactic acid from LAB metabolism during the fermentation process, so that the $\mathrm{pH}$ value tends to decrease [28]. This is in line with Sidupa's research [23], where the $\mathrm{pH}$ value of fermented yam flour by $\mathrm{LAB}$ from Wakawondu brown rice washing water decreased from 6.41 to 5.94 .

\subsection{Gel Visual Analysis}

Gelatinization is a process of breaking down the crystalline form of starch granules, so that each layer of the surface of the molecule can absorb water or dissolve and react with other materials and the condition cannot return to its original state. Some of the benefits of gelatinization in starch are the abilities to increase the absorption of some water, to increase the speed of enzymatic reactions (amylase) to break down starch bonds into simpler forms that are easily soluble, and to increase food conversion and digestibility [24]. The visualization of the gelling properties of Warumbia brown rice flour can be seen in Fig. 1.

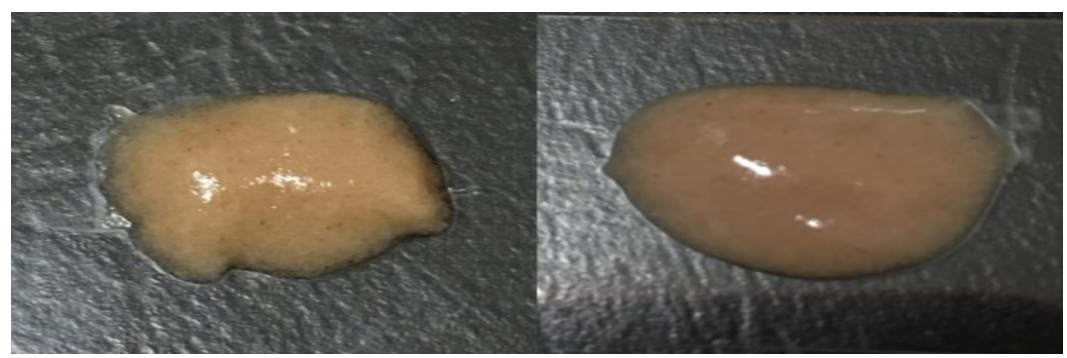

(a)

(b)

Fig. 1. Visualization of Warumbia brown rice flour gel (a) Warumbia brown rice flour without treatment (control) (b) selected Warumbia brown rice flour with treatment

The differences in the formed gel can be seen visually. In Fig. 1, the gel formed with 48 hours of fermentation time with a concentration of OD 0.75 has a characteristic that looks thicker and has a dark brown color when compared to the control Warumbia brown rice flour. 


\subsection{FTIR Analysis}

The result of the FTIR spectrum obtained was a comparison of the absorption bands of the control Warumbia cultivar brown rice flour and the modified Warumbia cultivar brown rice flour. The sample spectrum shows the same absorption at a wavelength of $3402.43 \mathrm{~cm}^{-}$ 1 indicating the presence of a carboxylic acid group $(\mathrm{COOH})$ with a strong absorption intensity, $2368.59 \mathrm{~cm}^{-1} ; 1651.07$ indicates the formation of an alkene group $(\mathrm{C}=\mathrm{C})$; $1527.62 \mathrm{~cm}-1$ indicates the presence of an aromatic group; $1419.61 \mathrm{~cm}^{-1} ; 1373.32 \mathrm{~cm}^{-1}$, $1157.29 \mathrm{~cm}^{-1}$ indicates the presence of a fluoride group (C-X). While the difference in wavelength occurred in the carboxylic acid group with wavelengths of 2931.80 (control), 2924.09 (selected) and 2854.65 (selected); indicating alkyne groups at wavelengths of $2137.13 \mathrm{~cm}^{-1}$ (control), $2090.84 \mathrm{~cm}^{-1}$ (control), $2337.72 \mathrm{~cm}^{-1}$ (selected) and $2152.56 \mathrm{~cm}^{-1}$ (selected); indicates the fluoride group (C-X) at a wavelength of $1018.41 \mathrm{~cm}^{-1}$ (control), $1026.13 \mathrm{~cm}^{-1}$ (selected). Based on the identification results, it can be seen that the modification of functional groups occurs due to the interaction of LAB in flour [18].

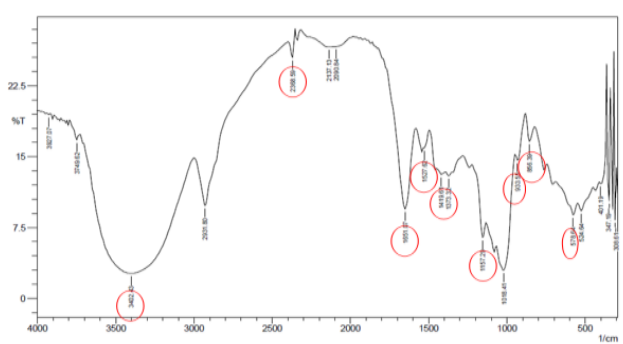

(a)

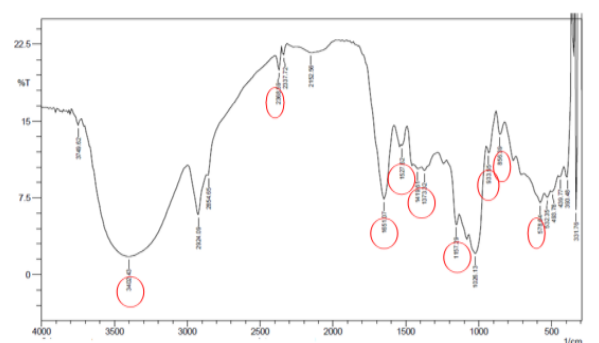

(b)

Fig. 2. FTIR Spectrum (a) Control Warumbia cultivar brown rice flour (b) Selected modified Warumbia cultivar brown rice flour

\subsection{X-Ray Difraction (XRD) Analysis}

The purpose of XRD analysis on Warumbia cultivar brown rice flour was to determine the XRD pattern that characterizes crystalline starch grains. It can be seen from the peak position with the highest intensity on the Warumbia cultivar brown rice flour without modification that was at $17,06^{\circ}-22,92^{\circ}(2 \theta)$. Meanwhile, the peak position with the highest intensity on the modified Warumbia cultivar brown rice flour was at $18,84^{\circ}-23,08^{\circ}(2 \theta)$. This indicates that the Warumbia cultivar brown rice flour has type A starch. This is supported by Faridah et al. [29] who stated that crystalline type A starch is characterized by the peak at $15^{\circ}, 17^{\circ}, 20^{\circ}$, dan $23^{\circ}(2 \theta)$. The peak intensity between the control and selected flour shows that the control flour had a lower peak intensity than the selected flour. It is seen from Figure 3 that the fermentation process could increase the peak intensity, and the longer the fermentation time, the more the peak intensity decreased. This indicates that the Warumbia cultivar brown rice flour had been modified. 


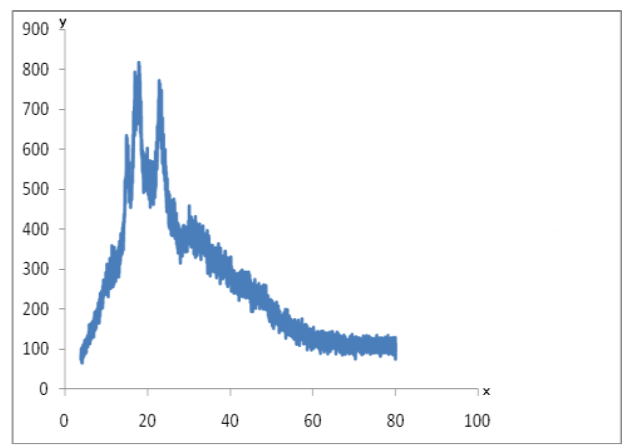

(a)

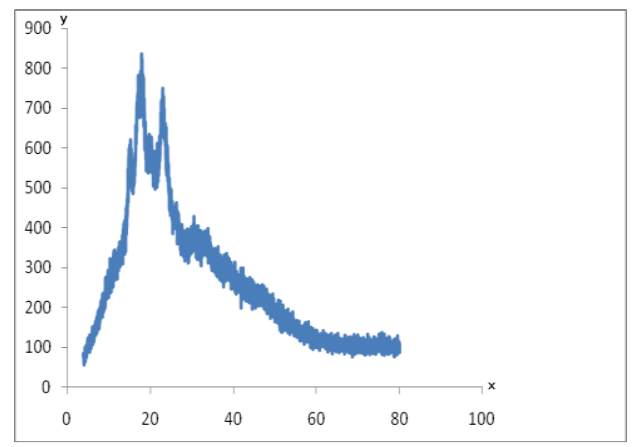

(b)

Fig. 3. XRD patterns of flour. (a) Control Warumbia cultivar brown rice flour (b) Selected modified Warumbia cultivar brown rice flour

\subsection{RVA Analysis}

Based on the data inTable 2 shows the gelatinization profile data of the Warumbia cultivar brown rice flour obtained from the curve of Fig. 4.

Table 2. Results of RVA analysis of Warumbia cultivar brown rice

\begin{tabular}{|c|c|c|c|c|c|}
\hline Treatment & $\begin{array}{c}\text { Peak } \\
\text { viscosity } \\
\text { (mPas) }\end{array}$ & $\begin{array}{c}\text { Breakdown } \\
\text { viscosity }\end{array}$ & $\begin{array}{c}\text { Setback } \\
\text { viscosity }\end{array}$ & $\begin{array}{c}\text { Final } \\
\text { viscosity }\end{array}$ & $\begin{array}{c}\text { Pasting } \\
\text { Temp } \\
\text { ('C) }\end{array}$ \\
\hline $\begin{array}{c}\text { Control Warumbia } \\
\text { cultivar brown rice }\end{array}$ & 1553 & 148 & 256 & 1661 & 72.00 \\
\hline $\begin{array}{c}\text { Modified } \\
\text { Warumbia cultivar } \\
\text { brown rice }\end{array}$ & 1291 & 221 & 210 & 1280 & 71.75 \\
\hline
\end{tabular}

The peak viscosity of the modified Warumbia cultivar brown rice flour was reached at the temperature of $95{ }^{\circ} \mathrm{C}$ which was higher than that of the control Warumbia cultivar brown rice flour that was at $92{ }^{\circ} \mathrm{C}$, and the time required for the peak viscosity of modified flour to occur was faster, that is 6.67 minutes, while the control flour took 7 minutes to reach peak viscosity. This is in contrast to the statement reported by Kartikasari et al. [30] that the longer the fermentation process, the higher the temperature and time of peak viscosity. The peak viscosity of the Warumbia cultivar brown rice flour without modification was $1553 \mathrm{mPas}$, while the Warumbia cultivar brown rice fermented by SBM.3D LAB was $1291 \mathrm{mPas}$, and the temperature required for complete gelatinization of the modified Warumbia cultivar brown rice flour was lower at 71.75 than the control flour, that was 72.00 . 


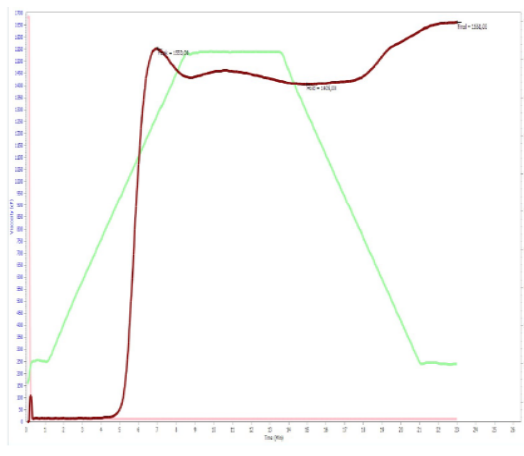

(a)

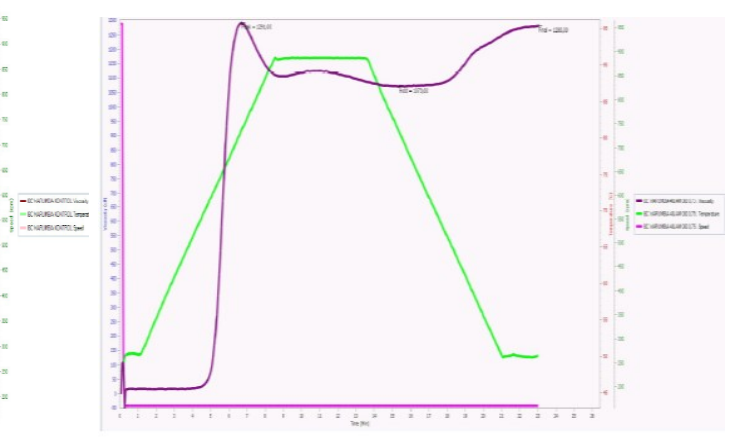

(b)

Fig. 4. RVA pattern of flour (a) Control Warumbia cultivar brown rice flour (b) Selected modified Warumbia cultivar brown rice flour

\subsection{Proximate Content of Selected Modified Warumbia Cultivar Brown Rice Flour}

Based on the data in Table 3, it can be seen that the observed variables on the dissolved protein content of the selected Warumbia brown rice flour were significantly different from the control, whereas the water content, ash content and glucose content of the Warumbia brown rice flour were not significantly different from the control. The selected Warumbia brown rice flour experienced an increase in water content, dissolved protein content and glucose content respectively by $1.14 \%, 5.77 \%$ and $1.36 \%$, whereas the ash content decreased by $0.25 \%$, so that the water content, ash content, dissolved protein content and glucose content of the Warumbia brown rice flour were modified to, respectively, $8.37 \%$ wb, $0.66 \% \mathrm{db}, 10.52 \% \mathrm{db}$ and $8.05 \% \mathrm{db}$, so that they met the quality requirements of rice flour according to SNI 3549-2009 standard.

Table 3. Proximate content of selected fermented Warumbia brown rice flour

\begin{tabular}{|c|c|c|c|c|}
\hline \multirow{2}{*}{ Component } & \multicolumn{3}{|c|}{ Perlakuan } & SNI 3549-2009 \\
\cline { 2 - 4 } & $\begin{array}{c}\text { Control } \\
\text { (Warumbia } \\
\text { brown rice } \\
\text { flour) }\end{array}$ & $\begin{array}{c}\text { Selected } \\
\text { Warumbia } \\
\text { brown rice } \\
\text { flour }\end{array}$ & Change (\%) & Mality (*) \\
\hline $\begin{array}{c}\text { Water Content } \\
(\% \mathrm{wb})\end{array}$ & $7.23 \pm 0.15$ & $8.37^{\mathrm{ns}} \pm 1.48$ & +1.14 & Max 1.0 \\
\hline $\begin{array}{c}\text { Ash Content } \\
(\% \mathrm{db})\end{array}$ & $0.91 \pm 0.05$ & $0.66^{\mathrm{ns}} \pm 0.17$ & -0.25 & - \\
\hline $\begin{array}{c}\text { Protein Content } \\
(\% \mathrm{db})\end{array}$ & $4.75 \pm 0.09$ & $10.52^{*} \pm 0.03$ & +5.77 & - \\
\hline $\begin{array}{c}\text { Glucose Content } \\
(\% \mathrm{db})\end{array}$ & $6.69 \pm 0.73$ & $8.05^{\mathrm{ns}} \pm 0.66$ & +1.36 & - \\
\hline
\end{tabular}

Note: The numbers followed by notations show $*=$ significant difference; $n s=$ not significantly different based on the $\mathrm{T}$ test with $95 \%$ confidence level $(\mathrm{p}<0.05),-=$ decreased, $+=$ increased

The water content of the modified Warumbia brown rice flour produced was $8.37 \% \mathrm{wb}$. The water content in the modified Warumbia brown rice flour product was higher than the water content in the Warumbia brown rice flour without modification (control) that was 
$7.23 \% \mathrm{wb}$. Based on the results of the research, the selected fermented Warumbia brown rice flour has met the water content standard of SNI 3549-2009 regarding the rice flour quality standard of a maximum of $13 \%$, thus it is safe from the risk of mold growth. Purnomo [25] argued that the storage conditions of flour also greatly affect the water content.

The ash content of the modified Warumbia cultivar brown rice flour product was $0.66 \%$ $\mathrm{db}$ and has met the quality requirements of rice flour, which is a maximum of $1.0 \% \mathrm{db}$. This indicates that there has been a decrease in inorganic mineral content in the brown rice flour after fermentation. The decrease in ash content could be influenced by the washing and fermentation processes. Mahendra et al. (2019) stated that the loss of water-soluble minerals such as potassium and sodium is caused by the soaking/washing process which result in these minerals being dissolved and wasted. Oetami (2012) stated that the decrease in minerals occurs because bacteria utilize minerals as a source of nutrition, although in small quantities. This is because minerals are needed by bacteria in glucose metabolism, enzyme activators, including in exopolysaccharide polymerization reactions so that there is a reduction in minerals during the fermentation process.

The dissolved protein content in the modified Warumbia brown rice flour increased by $10.52 \% \mathrm{db}$ compared to the Warumbia brown rice flour without treatment (control), that was $4.75 \% \mathrm{db}$. Adnan [9] reported that SBM.3D LAB isolate reacted positively to the casein hydrolysis test, which means that the isolate can produce protease enzymes. This provides information that the isolate can produce protease enzymes that will decompose proteins into small peptides and amino acids that make up the protein with the help of protease or peptidase enzymes. This result is in line with that reported by Sidupa [23] that the protein content of selected yam flour with fermentation using LAB isolate from Wakawondu brown rice washing water resulted in a protein content of $5.01 \% \mathrm{db}$, higher than the control yam with a protein content of $4.30 \% \mathrm{db}$.

The glucose content in the modified Warumbia brown rice flour produced was $8.05 \%$ $\mathrm{db}$. The glucose content in the modified Warumbia brown rice flour product was higher than the glucose content in the Warumbia brown rice flour without modification (control) that was at $6.69 \% \mathrm{db}$. The increase in glucose content was caused by the SBM.3D LAB microorganism which includes homofermentative bacteria that can produce lactic acid through the process of glycolysis/glucose breakdown [26]. This is what caused the increase in the glucose content in the modified Warumbia brown rice flour. This result is in line with that reported by Stevi et al. [27] that the longer the fermentation time, the higher the total sugar content produced, because during the fermentation process, there is a breakdown of starch into reducing sugars such as monosaccharides including glucose.

\section{Conclusion}

The best fermentation time in the production of modified brown rice flour was 48 hours using SBM.3D LAB isolate with $\mathrm{OD}=0.75$. The interaction of SBM.3D type LAB and LAB concentration of $\mathrm{OD}=0.75$ significantly affected the physicochemical characteristics of the modified flour on the viscosity and $\mathrm{pH}$ variables. However, it had no significant effect on the swelling power and water solubility index variables. The fermentation process showed an increase in the proximate content of the modified Warumbia brown rice flour.

The authors express their gratitude to the Ministry of Research, Technology and Higher Education for funding this research through the 2021 Higher Education Leading Applied Research Program of Halu Oleo University. 


\section{References}

1. Badan Pusat Statistik Nasional. Ringkasan Eksekutif Luas Panen dan Produksi Beras di Indonesia 2018 (Jakarta: Badan Pusat Statistik Nasional) (2018)

2. Badan Pusat Statistik Sulawesi Tenggara. Luas Panen dan Produksi Padi di Sulawesi Tenggara 2018 (Kendari: Badan Pusat Statistik Sulawesi Tenggara) (2018)

3. Savira APIS. Analisis Kandungan Gizi, Organoleptik dan Aktivitas Antioksidan Snack Bar Berbasis Beras Warna Organik (Oryza sativa L.) Varietas Lokal (Merah Wakawondu, Hitam Wakombe dan Coklat Warumbia) Sebagai Alternatif Makanan Selingan Penderita Diabetes Melitus (Skripsi) (Kendari: Ilmu dan Teknologi Pangan Universitas Halu Oleo) (2019)

4. Hasnelly, Sumartini. Kajian Sifat Fisiko Kimia Formulasi Tepung Komposit Produk Organik, Seminar Nasional PATPI 375-379 (2011)

5. I. Kuswardani, C.Y. Trisnawati, Faustine, Jurnal Teknologi Pangan dan Gizi, 71 pp 55-65 (2008)

6. N. Nurhayati, Giyarto, D.P. Ariyanti, Jurnal Agroteknologi. 82 pp 101-111 (2014)

7. H. Helmi, Formulasi Kultur Starter Untuk Pembuatan Tepung Ubi Kayu Terfermentasi (Tesis)( Bogor: Institut Pertanian Bogor) (2011)

8. R. Eni, Jurnal Teknik Kimia. 211 pp 14-21 (2015)

9. N.S. Adnan. Isolasi dan Karakterisasi Bakteri Asam Laktat (BAL) dari Fermentasi Air Cucian Beras Merah (Oryza nivara) (Skripsi)(Kendari: Ilmu dan Teknologi Pangan Universitas Halu Oleo) (2018)

10. D. Ashari, Modifikasi tepung keladi (Calodium bicolor) menggunakan bakteri asam laktat (BAL) asal wikau mambo dan aplikasinya pada pembuatan biskuit crackers untuk penderita autis (Skripsi)(Kendari: Ilmu dan Teknologi Pangan Universitas Halu Oleo) (2018)

11. K.S. Sutiah, Firdaus, W.S. Budi, Berkala Fisika, 112 pp 53-58 (2008)

12. S. Senanayake, A. Gunaratne, K.K.D.S. Ranawera, A. Bamunuarachchi, Hindawi Publishing Corporation 1-4 (2013)

13. N. Imanningsih, Penel Gizi Makan, 351 pp 13-22 (2012)

14. AOAC Official Method of Analysis of the Association of Official Analysis Chemist 18th ed Maryland: (AOAC International William Harwitz, United States of America, 2005)

15. S. Zikirah. Pengaruh Penambahan BAL (Bakteri Asam Laktat) Asal Air Cucian Beras Merah Wakawondu pada Pembuatan Tepung Ubi Kano (Dioscorea rotundata) Terhadap Fisikokimia dan Organoleptik Cookies (Skripsi)(Kendari: Ilmu dan Teknologi Pangan Universitas Halu Oleo) (2019)

16. A. Kusumaningrum, S. Sumardiono, Jurnal Aplikasi Teknologi Pangan, 52 pp 31-33 (2016)

17. A. Subagio, Modified Cassava Flour Masa Depan Ketahanan Pangan Nasional Berbasis Potensi Lokal (Jember: FTIP Universitas Jember) 92-103 (2009)

18. S. Wahyuni, Ansharullah, Saefuddin, Asranudin and Holilah, Journal of Food Measurement and Characterization, 11 pp 329-336 (2017)

19. H. Marta, Sifat Fungsional dan Reologi Tepung Jagung Nikstamal Serta Contoh Aplikasinya pada Pembuatan Makanan Pendamping ASI (Bogor: Sekolah Pasca Sarjana Institut Pertanian) (2011) 
20. W.D.R. Putri, Haryadi, W.M. Djagal, C. Nur, Jurnal Teknologi Pertanian. 131 pp $52-$ 60 (2012)

21. A. Hakim, F Sistihapsari. Modifikasi Fisik-Kimia Tepung Sorghum Berdasarkan Karakteristik Sifat Fisikokimia Sebagai Substituen Tepung Gandum (Skripsi)(Semarang: Fakultas Teknik Universitas Diponegoro) (2011)

22. A.R. Sidabutar, Feliatra, A. Dahliaty. Uji Aktivitas Antimikroba Bakteriosin dari Bakteri Probiotik yang Diisolasi dari Udang Windu (Penaeus monodon Fabricus (Skripsi)(Pekanbaru: Fakultas Perikanan dan Ilmu Kelautan Universitas Riau) (2015)

23. H.E. Sidupa, Sifat Fisikokimia Tepung Gadung (Dioscorea Hispida Dennts) Termodifikasi dengan Menggunakan Isolat Bakteri Asam Laktat (SBM.3D dan SBM.4A) Asal Wakawondu dan Aplikasinya pada Pembuatan Mie Basah [ (Skripsi)(Kendari: Ilmu dan Teknologi Pangan Universitas Halu Oleo) (2019)

24. A. Smith, Studi tentang ekstraksi, sifat-sifat Fisikokimia Pati Sagu dan Pengkajian Enzim (Fakultas Teknologi Pertanian Institut Pertanian Bogor, Bogor, 1985)

25. Purnomo. Aktivitas Air dan Peranannya dalam Pengawetan Pangan[Activity Of Water And Its Role In Food Preservation] (Universitas Indonesia, Jakarta, 1995)

26. U. Kunaepah, Pengaruh Lama Fermentasi dan Konsentrasi Glukosa terhadap Aktivitas Antibakteri, Polifenol Total dan Mutu Kimia Kefir Susu Kacang Merah. (Tesis)(Semarang: Universitas Diponegoro) (2008)

27. M.E. Stevi, Nurhaeni, Indriani, dan Jusman, Jurnal Riset Kimia. 51 pp 78-89 (2019)

28. G.P.A.W. Kusuma, K.A. Nocianitri, I.D.P.K. Pratiwi, Jurnal Itepa, 92 pp 182-193 (2020)

29. D.N. Faridah, D. Fardiaz, N. Andarwulan, dan T.C. Sunarti, AGRITECH. 341 pp 1421 (2014)

30. S.N. Kartika, P. Sari, A. Subagio, Jurnal Agroteknologi. 101 pp 12-24 (2016)

31. I.M. Demiate, M.P. Cereda, A.C. Barana, G. Wosiacki. Organic Acid Profile Of Commercial Sour Cassava Starch. Food Science and Technology (Campinas) $191 \mathrm{pp}$ 1-7 (1999) 